OPEN ACCESS

Edited by:

Xu Zhang,

Jiangsu University, China

Reviewed by:

Wen Zhou,

Guangzhou University of Chinese

Medicine, China

Xin Luan,

Shanghai University of Traditiona

Chinese Medicine, China

${ }^{*}$ Correspondence:

Jiang-Jiang Qin

jqin@zcmu.edu.cn;

zylysjtu@hotmail.com

Specialty section:

This article was submitted to Pharmacology of Anti-Cancer Drugs,

a section of the journal

Frontiers in Pharmacology

Received: 27 May 2020

Accepted: 18 June 2020

Published: 30 June 2020

Citation:

Yu W-K, Xu Z-Y, Yuan L, Mo S, Xu B, Cheng X-D and Qin J-J (2020)

Targeting $\beta$-Catenin Signaling by

Natural Products for Cancer

Prevention and Therapy.

Front. Pharmacol. 11:984.

doi: 10.3389/fphar.2020.00984

\section{Targeting $\beta$-Catenin Signaling by Natural Products for Cancer Prevention and Therapy}

\author{
Wen-Kai Yu ${ }^{1}$, Zhi-Yuan $X^{2}{ }^{2}$, Li Yuan ${ }^{3}$, Shaowei Mo ${ }^{3}$, Beihua X ${ }^{1}{ }^{1}$ Xiang-Dong Cheng ${ }^{2}$ \\ and Jiang-Jiang Qin ${ }^{1,2 *}$
}

${ }_{1}$ College of Pharmaceutical Sciences, Zhejiang Chinese Medical University, Hangzhou, China, 2 Institute of Cancer and Basic Medicine, Chinese Academy of Sciences, Cancer Hospital of the University of Chinese Academy of Sciences, Zhejiang Cancer Hospital, Hangzhou, China, ${ }^{3}$ The First Affiliated Hospital of Zhejiang Chinese Medical University, Hangzhou, China

The mutations and deregulation of Wnt signaling pathway occur commonly in human cancer and cause the aberrant activation of $\beta$-catenin and $\beta$-catenin-dependent transcription, thus contributing to cancer development and progression. Therefore, $\beta$ catenin has been demonstrated as a promising target for cancer prevention and therapy. Many natural products have been characterized as inhibitors of the $\beta$-catenin signaling through down-regulating $\beta$-catenin expression, modulating its phosphorylation, promoting its ubiquitination and proteasomal degradation, inhibiting its nuclear translocation, or other molecular mechanisms. These natural product inhibitors have shown preventive and therapeutic efficacy in various cancer models in vitro and in vivo. In the present review, we comprehensively discuss the natural product $\beta$-catenin inhibitors, their in vitro and in vivo anticancer activities, and underlying molecular mechanisms. We also discuss the current $\beta$-catenin-targeting strategies and other potential strategies that may be examined for identifying new $\beta$-catenin inhibitors as cancer preventive and therapeutic drugs.

Keywords: $\beta$-catenin, cancer prevention and therapy, degradation, inhibitors, natural products, phosphorylation

\section{INTRODUCTION}

$\beta$-Catenin was initially discovered as one of the E-cadherin-associated molecules on the cell membrane and the E-cadherin/ $\beta$-catenin complex contributes to $\mathrm{Ca}^{2+}$-dependent cell-cell adhesion (Ozawa et al., 1989; Ozawa et al., 1990). $\beta$-Catenin was found to play an essential role in the embryonic development of Drosophila melanogaster (Wieschaus et al., 1984). In the saturation mutagenesis screens for identifying genes that regulate the segmentation of Drosophila embryo, the Drosophila ortholog of the mammalian $\beta$-catenin gene (CTNNB1), termed armadillo has been found to affect the formation of denticles and naked belts (Wieschaus et al., 1984). Further analysis has characterized the $\mathrm{Wnt} / \beta$-catenin pathway by demonstrating the critical role of Wnt proteins in activating the $\beta$-catenin signaling pathway (Riggleman et al., 1990). In the canonical Wnt/ $\beta$-catenin signaling pathway, $\beta$-catenin functions as a coactivator of the transcription factor $\mathrm{T}$ cell factor/ lymphocyte enhancer factor (TCF/LEF) and promotes the transcription of Wnt target genes, which are responsible for controlling cell fate in various diseases, including cancer (Cui et al., 2018). 
$\beta$-Catenin is overexpressed and constitutively activated in human cancer and contributes to cancer initiation, progression, metastasis, drug resistance, and immune evasion (Pai et al., 2017; Cui et al., 2018). Targeting $\beta$-catenin signaling has been proposed as a promising strategy to develop effective anticancer agents (Qin et al., 2018b; Cheng et al., 2019). Recent advances in understanding the protein structures of $\beta$-catenin alone and complexed with its coactivators have promoted the design and development of specific small-molecule inhibitors (Krishnamurthy and Kurzrock, 2018; Zhang X. et al., 2020). These $\beta$-catenin signaling inhibitors have shown anticancer efficacy in preclinical settings, and some of them have entered clinical trials, such as PRI-724 (Krishnamurthy and Kurzrock, 2018). However, none of these $\beta$-catenin inhibitors has been approved for clinical use yet. It is still urgently needed to identify more specific, safe, and effective $\beta$-catenin inhibitors for cancer treatment.

Natural products and their derivatives represent a major source for anticancer drug discovery (Qian et al., 2013; Qin et al., 2017). Over the past few decades, about 33.5\% of FDAapproved anticancer drug entities are identified from natural products or their derivatives (Newman and Cragg, 2020). Many natural products have been found to exert their anticancer activity by inhibiting oncoproteins (e.g. $\beta$-catenin and MDM2) and/or reactivating tumor suppressors (e.g. p53 and Puma) (Li et al., 2013; Qin et al., 2018a; Wang W. et al., 2018; Wang et al., 2020; Zhang J. et al., 2020). It has also been reported that natural products can enhance the chemosensitivity of cancer cells by suppressing the functions of drug resistance-related proteins (Feng et al., 2017; Dong et al., 2020; Yuan et al., 2020). Recent studies have identified several natural products with potent inhibitory effects on the $\beta$-catenin signaling and shown promising anticancer efficacy in vitro and in vivo, such as baicalin (Zhou et al., 2017), arctigenin (Lee et al., 2017), and rhein (Liu et al., 2018). In the present review, we comprehensively discuss the natural products that target the $\beta$-catenin signaling, their in vitro and in vivo anticancer activities, and underlying molecular mechanisms. Moreover, we summarize known naturalproduct-based $\beta$-catenin-targeting strategies and propose new strategies that may be used to identify more specific and effective $\beta$-catenin inhibitors for cancer prevention and therapy.

\section{WNT/ $\beta$-CATENIN SIGNALING PATHWAY}

The Wnt/ $\beta$-catenin pathway (Figure 1) plays an important role in cancer development and progression by promoting the cytoplasmic accumulation and nuclear translocation of $\beta$ catenin and activating the transcription of genes related to cancer cell proliferation, cell cycle progression, anti-apoptosis, migration, invasion, and drug resistance (Krishnamurthy and Kurzrock, 2018). In the absence of Wnt stimulation, $\beta$-catenin is phosphorylated by the destruction complex (Figure 1A), which includes Axin, adenomatous polyposis coli (APC), glycogen synthase kinase 3 (GSK3), and casein kinase $1 \alpha$ (CK1 $\alpha$ ) (Stamos and Weis, 2013). When $\beta$-catenin is recruited to the destruction complex, CK1 $\alpha$ initially phosphorylates $\beta$-catenin at Ser45 and
GSK3 $\beta$ further promotes $\beta$-catenin phosphorylation at Ser33, Ser37, and Thr41 (Amit et al., 2002; Liu et al., 2002; Wu and He, 2006). Subsequently, the phosphorylated $\beta$-catenin is recognized and ubiquitinated by the E3 ligase protein $\beta$-transducin repeatcontaining protein $(\beta-\operatorname{TrCP})$, which consequently results in the proteasomal degradation of $\beta$-catenin (Aberle et al., 1997; Orford et al., 1997; Stamos and Weis, 2013).

When the Wnt ligands bind to the cysteine-rich domain (CRD) of Frizzled (FZD) receptors (Figure 1B), the FZD co-receptors LRP5/6 (low-density lipoprotein receptor-related protein 5/6) will be recruited to form complexes with FZD and then phosphorylated, which further causes the disassembly of the destruction complex and the stabilization and accumulation of $\beta$-catenin in the cytoplasm (Cheng et al., 2019; Zhang X. et al., 2020). The Wnt/ FZD/LRP complex also activates Dishevelled, which further inhibits GSK3 $\beta$ and prevents $\beta$-catenin phosphorylation and inactivation (Cheng et al., 2019). The stable $\beta$-catenin then translocates into the nucleus and interacts with TCF/LEF to form the $\beta$-catenin/TCF/ LEF complex, thereby activating the transcription of downstream target genes (Krishnamurthy and Kurzrock, 2018).

\section{NATURAL PRODUCT INHIBITORS OF $\beta$-CATENIN SIGNALING PATHWAY}

As a well-recognized cancer driver gene, $\beta$-catenin has been demonstrated as a molecular target for developing anticancer drugs. Small-molecule inhibitors have been designed and synthesized for inhibiting the $\beta$-catenin/TCF binding or promoting $\beta$-catenin phosphorylation and ubiquitination (Zhang X. et al., 2020). Natural product-based libraries have also been frequently screened, leading to the identification of several $\beta$-catenin inhibitors (Table 1). These natural products have been found to inhibit the $\beta$-catenin signaling through different molecular mechanisms (Figure 2), including, but not limited to, 1) down-regulating $\beta$-catenin expression, 2) modulating $\beta$-catenin phosphorylation, 3) promoting $\beta$-catenin protein degradation, 4) inhibiting $\beta$-catenin nuclear translocation, and others.

\section{Down-Regulate $\beta$-Catenin Expression}

The majority of natural product inhibitors have been reported to down-regulate the expression of $\beta$-catenin and/or its coactivators, thereby inhibiting the transcription of its downstream target genes (Table 1). Flavonoids are a class of ubiquitous polyphenolic natural products in medicinal plants and have recently been found to exert anticancer activities by targeting the $\beta$-catenin signaling (Cheng et al., 2011b; Wang et al., 2011; Zhu et al., 2012a; Zhou et al., 2017). Baohuoside-I, a flavonoid from Cortex periplocae has been reported to down-regulate the expression of $\beta$-catenin and its downstream target gene Survivin and Cyclin D1 at both protein and mRNA levels (Wang et al., 2011). Wang et al. have also demonstrated that baohuoside-I inhibits the viability and induces apoptosis in esophageal cancer Eca109 cells in vitro and suppresses the growth of Eca109 xenograft tumors in vivo (Wang et al., 2011). Another flavonoid baicalin 


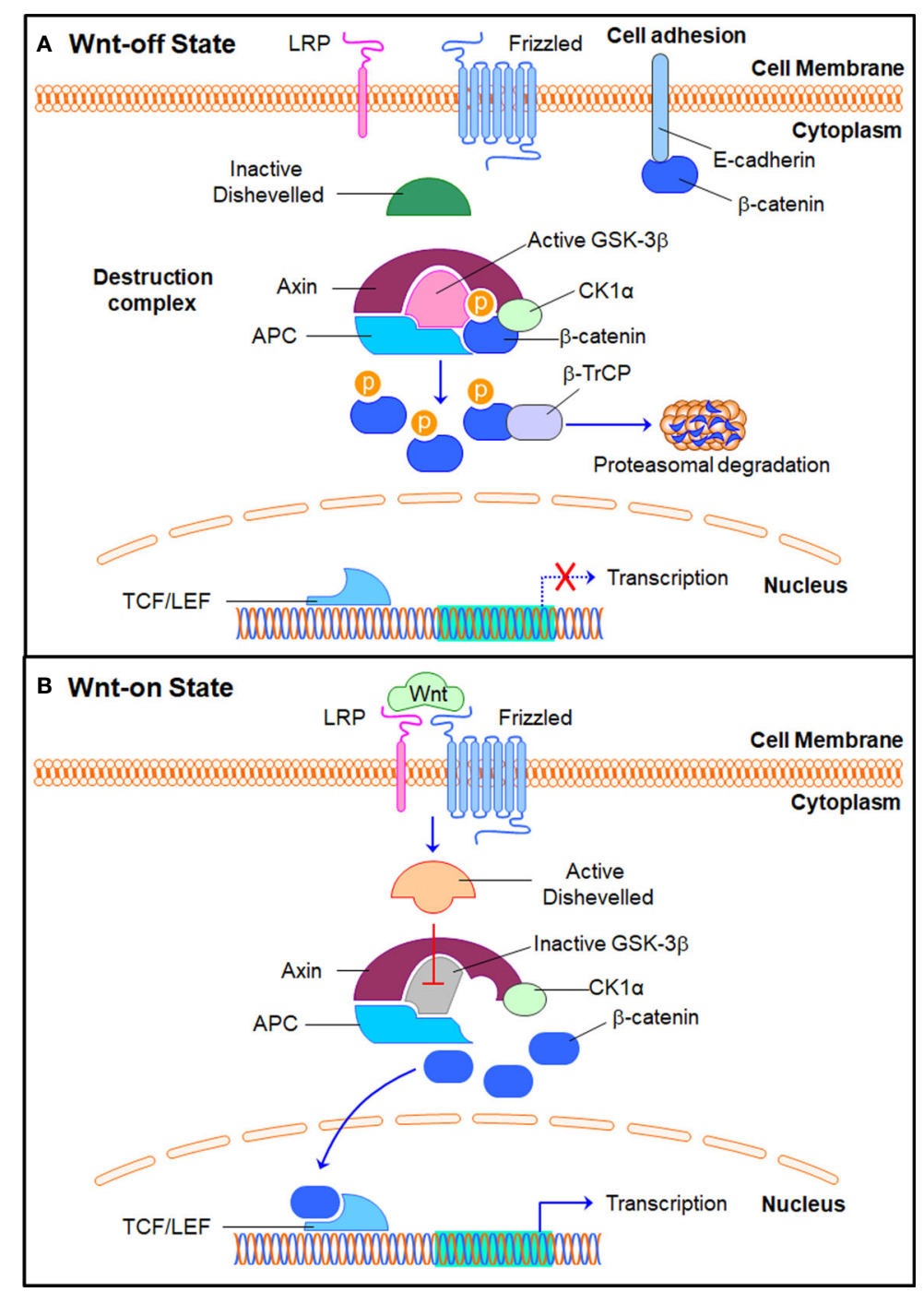

FIGURE 1 | The Wnt/ $\beta$-catenin signaling pathway. (A) In the Wnt-off state, the $\beta$-catenin destruction complex is formed by Axin, APC, GSK3 $\beta$, and CK1 $\alpha$ and promotes the phosphorylation of $\beta$-catenin. The E3 ligase $\beta$-TrCP further induces $\beta$-catenin ubiquitination and proteasomal degradation. E-cadherin and $\beta$-catenin also form complex to enhance cell adhesion. (B) In the Wnt-on state, Wnt proteins bind to Frizzled receptor and LRP co-receptor and recruit and activate Dishevelled, which further inhibits the activity of GSK3 $\beta$ and releases $\beta$-catenin from the destruction complex. The stable $\beta$-catenin subsequently translocates into the nucleus, interacts with TCF/LEF, and promotes the transcription of its down-stream target genes. APC, adenomatous polyposis coli; $\beta$-TrCP, $\beta$-Transducin repeat-

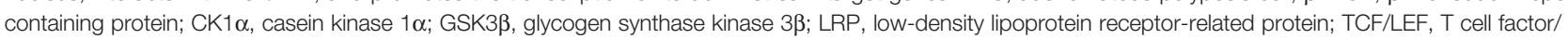
lymphocyte enhancer factor.

has been found to inhibit the migration and invasion of triple negative breast cancer MDA-MB-231 and $4 \mathrm{~T} 1$ cells in vitro by modulating the expression of epithelial-to-mesenchymal transition (EMT)-related proteins, including $\beta$-catenin (Zhou et al., 2017). Further studies have shown that baicalin prevents tumor metastasis to liver and lungs in mice bearing 4T1 xenograft tumors (Zhou et al., 2017). Importantly, the expression level of $\beta$-catenin is critical for the anti-metastatic activity of baicalin (Zhou et al., 2017). However, the detailed molecular mechanisms for their inhibitory effects on $\beta$-catenin expression are yet to be determined.
Lignans as a group of diphenolic natural products have exhibited inhibitory effects on $\beta$-catenin expression (Cheng et al., 2011a; Zhu et al., 2012b; Xia et al., 2013; Lee et al., 2017). Lee et al. have recently demonstrated that $\beta$-catenin is a molecular target of the lignan arctigenin (Lee et al., 2017). It has been found that arctigenin inhibits the proliferation of breast cancer MCF7 cells and induces apoptosis in vitro in an estrogen receptor (ER)-dependent manner (Lee et al., 2017). Arctigenin has also been shown to decrease the expression levels of $\beta$ catenin and its target Cyclin D1 via an ER-dependent mechanism (Lee et al., 2017). The lignan E2S from Carya 
TABLE 1 | Natural product $\beta$-catenin inhibitors and their activities and mechanisms of action.

\begin{tabular}{|c|c|c|c|c|}
\hline Inhibitors & Mechanisms of action & In vitro activity & In vivo activity & References \\
\hline \multicolumn{5}{|c|}{ Strategy 1. Down-regulate $\beta$-catenin expression } \\
\hline Baohuoside-I & $\begin{array}{l}\text { Down-regulates the expression of } \beta \text { - } \\
\text { catenin and its downstream targets at } \\
\text { both mRNA and protein levels }\end{array}$ & $\begin{array}{l}\text { Inhibits cell growth and induces apoptosis in } \\
\text { esophageal cancer Eca109 cells }\end{array}$ & $\begin{array}{l}\text { Suppresses tumor growth in } \\
\text { mice bearing Eca109 xenograft } \\
\text { tumors }\end{array}$ & (Wang et al., 2011) \\
\hline Baicalin & Down-regulates $\beta$-catenin expression & $\begin{array}{l}\text { Inhibits migration and invasion in breast } \\
\text { cancer MDA-MB-231 and } 4 \mathrm{~T} 1 \text { cells }\end{array}$ & $\begin{array}{l}\text { Prevents metastasis to liver and } \\
\text { lung in mice bearing } 4 \mathrm{~T} 1 \\
\text { xenograft tumors }\end{array}$ & (Zhou et al., 2017) \\
\hline Arctigenin & $\begin{array}{l}\text { Down-regulates } \beta \text {-catenin expression in } \\
\text { an ER-dependent manner }\end{array}$ & $\begin{array}{l}\text { Inhibits proliferation and induces apoptosis in } \\
\text { ER positive breast cancer MCF7 cells }\end{array}$ & NR & (Lee et al., 2017) \\
\hline Lignan E2S & Down-regulates $\beta$-catenin expression & $\begin{array}{l}\text { Inhibits the viability and induces cell cycle } \\
\text { arrest at the G1 phase in colon cancer cells }\end{array}$ & NR & (Xia et al., 2013) \\
\hline$\beta$-Elemene & $\begin{array}{l}\text { Down-regulates the expression of } \beta \text { - } \\
\text { catenin and TCF7 }\end{array}$ & $\begin{array}{l}\text { Inhibits cell viability, induces cell cycle arrest } \\
\text { at G1 phase and apoptosis, and prevents } \\
\text { migration and invasion in cervical cancer } \\
\text { SiHa cells }\end{array}$ & NR & (Wang L. t al., 2018) \\
\hline Shizukaol D & $\begin{array}{l}\text { Down-regulates the expression of } \beta \text { - } \\
\text { catenin, LRP, Dvl2, and Axin2 }\end{array}$ & $\begin{array}{l}\text { Inhibits cell growth and induces apoptosis in } \\
\text { liver cancer cells }\end{array}$ & NR & (Tang et al., 2016) \\
\hline $\begin{array}{l}2 \mathrm{O}(\mathrm{S})-25- \\
\mathrm{OCH}_{3}-\mathrm{PPD}\end{array}$ & $\begin{array}{l}\text { Down-regulates the expression of } \beta \text { - } \\
\text { catenin and its downstream targets }\end{array}$ & $\begin{array}{l}\text { Inhibits proliferation and induces apoptosis in } \\
\text { colon and lung cancer cells }\end{array}$ & NR & (Bi et al., 2009) \\
\hline $\begin{array}{l}20(S)- \\
\text { ginsenoside } \\
\text { Rh2 }\end{array}$ & $\begin{array}{l}\text { Down-regulates } \beta \text {-catenin expression at } \\
\text { both mRNA and protein levels }\end{array}$ & $\begin{array}{l}\text { Inhibits proliferation and induces cell cycle } \\
\text { arrest at G0/G1 phase and apoptosis in } \\
\text { leukemia KG-1a cells }\end{array}$ & NR & (Chen et al., 2016) \\
\hline$\beta$-Sitosterol & Down-regulates $\beta$-catenin expression & $\begin{array}{l}\text { Inhibit growth and induces apoptosis in } \\
\text { colon cancer COLO } 320 \text { DM cells }\end{array}$ & $\begin{array}{l}\text { Reduces the number of } \\
\text { aberrant crypt and crypt } \\
\text { multiplicity in } \mathrm{DMH} \text {-treated rats }\end{array}$ & (Baskar et al., 2010) \\
\hline Periplocin & Down-regulates $\beta$-catenin expression & $\begin{array}{l}\text { Inhibits the proliferation of colon cancer } \\
\text { HCT116 cells }\end{array}$ & $\mathrm{NR}$ & (Kim et al., 2017) \\
\hline Evodiamine & Down-regulates $\beta$-catenin expression & $\begin{array}{l}\text { Inhibits proliferation, invasion, and migration } \\
\text { of HCC HepG2 and SMMC-7721 cells }\end{array}$ & $\begin{array}{l}\text { Suppresses tumor growth and } \\
\text { angiogenesis in mice bearing } \\
\mathrm{H} 22 \text { and SMMC- } 7721 \\
\text { xenograft tumors }\end{array}$ & (Shi et al., 2016) \\
\hline Resveratrol & $\begin{array}{l}\text { Down-regulates the expression of } \beta \text { - } \\
\text { catenin and c-Myc }\end{array}$ & $\begin{array}{l}\text { Inhibits cell proliferation and induces } \\
\text { apoptosis in LNCaP and MES-SA cells }\end{array}$ & $\begin{array}{l}\text { Suppresses tumor growth in } \\
\text { mice bearing LNCaP xenograft } \\
\text { tumors }\end{array}$ & $\begin{array}{l}\text { (Mitani et al., 2014; } \\
\text { Mineda et al., 2019) }\end{array}$ \\
\hline PEITC & $\begin{array}{l}\text { Reduces the levels of phosphorylated } \\
\text { GSK3 } \beta \text { and } \beta \text {-catenin }\end{array}$ & $\begin{array}{l}\text { Suppresses the properties of CSCs, inhibits } \\
\text { proliferation, and induces apoptosis in colon } \\
\text { cancer cells }\end{array}$ & NR & (Chen et al., 2018) \\
\hline Gigantol & $\begin{array}{l}\text { Reduces the levels of phosphorylated } \\
\text { LRP6, } \\
\text { total LRP6, and cytosolic } \beta \text {-catenin }\end{array}$ & $\begin{array}{l}\text { Inhibits the viability and migration of breast } \\
\text { cancer cells }\end{array}$ & NR & (Yu et al., 2018) \\
\hline $\begin{array}{l}\text { Polysaccharide } \\
\text { from Phellinus } \\
\text { linteus }\end{array}$ & $\begin{array}{l}\text { Down-regulates the expression of } \beta \text { - } \\
\text { catenin and cyclin D1 }\end{array}$ & $\begin{array}{l}\text { Inhibits growth, invasion, and motility of } \\
\text { colon cancer SW } 480 \text { cells }\end{array}$ & $\begin{array}{l}\text { Suppresses tumor growth in } \\
\text { mice bearing SW } 480 \text { xenograft } \\
\text { tumors }\end{array}$ & (Song et al., 2011) \\
\hline Riccardin D & $\begin{array}{l}\text { Down-regulates the expression of } \beta \text { - } \\
\text { catenin and cyclin D1 }\end{array}$ & NR & $\begin{array}{l}\text { Prevents intestinal adenoma } \\
\text { formation in } A P C^{M i n /+} \text { mice }\end{array}$ & (Liu et al., 2012) \\
\hline \multicolumn{5}{|c|}{ Strategy 2. Modulate $\beta$-catenin phosphorylation } \\
\hline Fisetin & $\begin{array}{l}\text { Induces } \beta \text {-catenin phosphorylation and } \\
\text { inhibits the expression and nuclear } \\
\text { translocation of TCF1 and TCF4 }\end{array}$ & $\begin{array}{l}\text { Inhibits viability and induces apoptosis in } \\
\text { colon cancer HCT116 and HT29 cells }\end{array}$ & NR & (Suh et al., 2009) \\
\hline Honokiol & $\begin{array}{l}\text { Induces } \beta \text {-catenin phosphorylation at } \\
\mathrm{Ser}^{45}, \mathrm{Ser}^{33 / 37} \text { and } \mathrm{Thr}^{41}\end{array}$ & Inhibits the migration of NSCLC cells & NR & (Singh and Katiyar, 2013b) \\
\hline $4 \beta-H W E$ & $\begin{array}{l}\text { Induces } \beta \text {-catenin phosphorylation at } \\
\mathrm{Ser}^{33}, \mathrm{Ser}^{37} \text {, and } \mathrm{Thr}^{41} \text { and inhibits its } \\
\text { nuclear translocation }\end{array}$ & $\begin{array}{l}\text { Inhibits proliferation and induces cell cycle } \\
\text { arrest at G0/G1 phase and apoptosis in } \\
\text { colon cancer cells }\end{array}$ & $\begin{array}{l}\text { Suppresses tumor growth in } \\
\text { mice bearing HCT116 } \\
\text { xenograft tumors }\end{array}$ & (Ye et al., 2019) \\
\hline $\begin{array}{l}\text { Ethanol extract } \\
\text { of Scutellaria } \\
\text { barbata D. Don }\end{array}$ & $\begin{array}{l}\text { Induces } \beta \text {-catenin phosphorylation and } \\
\text { reduces } \beta \text {-catenin expression }\end{array}$ & $\begin{array}{l}\text { Inhibits the proliferation and survival of HT-29 } \\
\text { cells }\end{array}$ & $\begin{array}{l}\text { Suppresses tumor growth in } \\
\text { mice bearing HT-29 xenograft } \\
\text { tumors }\end{array}$ & (Wei et al., 2017) \\
\hline Shikonin & $\begin{array}{l}\text { Inhibits } \beta \text {-catenin phosphorylation at } \\
\text { Y333 }\end{array}$ & $\begin{array}{l}\text { Inhibits proliferation, migration, and invasion } \\
\text { of glioblastoma U87 and U251 cells }\end{array}$ & NR & (Zhang et al., 2015) \\
\hline \multicolumn{5}{|c|}{ Strategy 3. Promote $\beta$-catenin protein degradation } \\
\hline Wogonin & $\begin{array}{l}\text { Promotes } \beta \text {-catenin phosphorylation } \\
\text { and degradation }\end{array}$ & $\begin{array}{l}\text { Inhibits proliferation and induces cell cycle } \\
\text { arrest at G1 phase in colon cancer cells }\end{array}$ & $\begin{array}{l}\text { Suppresses tumor growth in } \\
\text { mice bearing HCT116 } \\
\text { xenograft tumors }\end{array}$ & (He et al., 2013) \\
\hline
\end{tabular}


TABLE 1 | Continued

\begin{tabular}{|c|c|c|c|c|}
\hline Inhibitors & Mechanisms of action & In vitro activity & In vivo activity & References \\
\hline Rhein & $\begin{array}{l}\text { Promotes } \beta \text {-catenin protein degradation } \\
\text { in GSK3-dependent manner }\end{array}$ & $\begin{array}{l}\text { Inhibits proliferation and induces cell cycle } \\
\text { arrest at S phase in HepG2 and Hela cells }\end{array}$ & $\begin{array}{l}\text { Suppresses tumor growth in } \\
\text { mice bearing HepG } 2 \text { xenograft } \\
\text { tumors }\end{array}$ & (Liu et al., 2018) \\
\hline Decursin & Promotes $\beta$-catenin protein degradation & $\begin{array}{l}\text { Inhibits the proliferation of prostate cancer } \\
\text { PC3 cells }\end{array}$ & NR & (Song et al., 2007) \\
\hline EGCG & $\begin{array}{l}\text { Promotes } \beta \text {-catenin phosphorylation } \\
\text { and degradation in a } \beta \text {-TrCP-dependent } \\
\text { manner }\end{array}$ & $\begin{array}{l}\text { Suppresses the properties of CSCs, inhibits } \\
\text { proliferation, and induces apoptosis in colon } \\
\text { cancer cells }\end{array}$ & NR & $\begin{array}{l}\text { (Dashwood et al., 2005; } \\
\text { Singh and Katiyar, 2013a; } \\
\text { Oh et al., 2014; Chen } \\
\text { et al., 2017) }\end{array}$ \\
\hline \multicolumn{5}{|c|}{ Strategy 4. Inhibit $\beta$-catenin nuclear translocation } \\
\hline Apigenin & Inhibits $\beta$-catenin nuclear translocation & $\begin{array}{l}\text { Inhibits proliferation and induces apoptosis in } \\
\text { prostate cancer DU145 cells }\end{array}$ & $\begin{array}{l}\text { Prevents prostate } \\
\text { tumorigenesis and metastasis } \\
\text { and improves overall survival in } \\
\text { TRAMP mice }\end{array}$ & (Shukla et al., 2007) \\
\hline Curcumin & $\begin{array}{l}\text { Inhibits } \beta \text {-catenin nuclear translocation } \\
\text { and the } \beta \text {-catenin/TCF-LEF binding to } \\
\text { the promoter DNA }\end{array}$ & $\begin{array}{l}\text { Inhibits the viability, migration, and invasion } \\
\text { and induces cell cycle arrest at G2/M phase } \\
\text { and apoptosis in osteosarcoma and colon } \\
\text { cancer cells }\end{array}$ & NR & $\begin{array}{l}\text { (Jaiswal et al., 2002; Leow } \\
\text { et al., 2010) }\end{array}$ \\
\hline Ellagic acid & Inhibits $\beta$-catenin nuclear translocation & NR & $\begin{array}{l}\text { Suppresses development of } \\
\text { carcinomas in the DMBA- } \\
\text { induced HBP carcinogenesis } \\
\text { model. }\end{array}$ & (Anitha et al., 2013) \\
\hline Isoeleutherine & $\begin{array}{l}\text { Inhibits } \beta \text {-catenin nuclear translocation } \\
\text { and TCF/ } \beta \text {-catenin transcription }\end{array}$ & Inhibits the viability of colon cancer cells & NR & (Li et al., 2009) \\
\hline $\begin{array}{l}\text { Toxoflavin } \\
\text { (PKF118-310) }\end{array}$ & Inhibits $\beta$-catenin nuclear translocation & $\begin{array}{l}\text { Inhibits the viability, migration, and invasion } \\
\text { and induces cell cycle arrest at G2/M phase } \\
\text { and apoptosis in osteosarcoma cells }\end{array}$ & NR & (Leow et al., 2010) \\
\hline \multicolumn{5}{|c|}{ Strategy 5. Others } \\
\hline Parthenolide & $\begin{array}{l}\text { Binds to RPL10, decreases TCF4/LEF1 } \\
\text { protein levels by blocking protein } \\
\text { synthesis, and inhibits Wnt/ } \beta \text {-catenin } \\
\text { signaling pathway }\end{array}$ & Inhibits proliferation of colon cancer cells & NR & (Zhu et al., 2018) \\
\hline Berbamine & $\begin{array}{l}\text { Decrease } \beta \text {-catenin protein levels by } \\
\text { binding to CaMKII } \gamma \text { and inhibiting its } \\
\text { kinase activity }\end{array}$ & $\begin{array}{l}\text { Induces apoptotic and autophagic death of } \\
\mathrm{CML} \text { cells }\end{array}$ & $\begin{array}{l}\text { Suppresses tumor growth in } \\
\text { mice bearing TKI-resistant } \\
\text { K562 or primary CML xenograft } \\
\text { tumors }\end{array}$ & (Gu et al., 2012) \\
\hline $\begin{array}{l}\text { Teucrium } \\
\text { polium plant } \\
\text { extract }\end{array}$ & $\begin{array}{l}\text { Enhances the formation of E-cadherin } / \beta \text { - } \\
\text { catenin complex and inhibits } \beta \text {-catenin } \\
\text { phosphorylation }\end{array}$ & $\begin{array}{l}\text { Inhibits proliferation, induces cell cycle arrest } \\
\text { at S phase, and reduces invasion and } \\
\text { motility of prostate cancer PC3 and DU145 } \\
\text { cells }\end{array}$ & NR & (Kandouz et al., 2010) \\
\hline $\begin{array}{l}\text { Alkaloid- } \\
\text { enriched } \\
\text { extract of } \\
\text { Uncaria } \\
\text { tomentosa }\end{array}$ & $\begin{array}{l}\text { Inhibits Wnt/ } \beta \text {-catenin signaling pathway } \\
\text { without affecting } \beta \text {-catenin level }\end{array}$ & Inhibits viability of colon cancer cells & NR & (Gurrola-Diaz et al., 2011) \\
\hline Dinactin & Inhibits Wnt/ $\beta$-catenin signaling pathway & $\begin{array}{l}\text { Inhibits the proliferation and induces cell } \\
\text { cycle arrest at G1/S phase in HCT116 and } \\
\text { HepG2 cells }\end{array}$ & NR & (Hussain et al., 2019) \\
\hline $\begin{array}{l}\text { Caffeoylquinic } \\
\text { acids }\end{array}$ & Inhibits TCF-4 expression & $\begin{array}{l}\text { Inhibits the viability of colon cancer HCT116 } \\
\text { cells }\end{array}$ & NR & (Taira et al., 2014) \\
\hline $\begin{array}{l}\text { Chromomycins } \\
\text { A2 and A3 }\end{array}$ & Inhibits $T C F / \beta$-catenin transcription & $\begin{array}{l}\text { Inhibits the viability of gastric } \\
\text { adenocarcinoma cells }\end{array}$ & NR & (Toume et al., 2014) \\
\hline
\end{tabular}

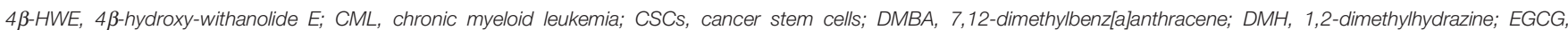
epigallocatechin-3-gallate; EMT, epithelial-to-mesenchymal transition; ER, estrogen receptor; HBP, hamster buccal pouch; HCC, hepatocellular carcinoma; NR, not reported; NSCLC, non-small cell lung cancer; PEITC, phenethyl isothiocyanate; TKI, tyrosine kinase inhibitor.

cathayensis fruits has also shown inhibitory effects on $\beta$-catenin expression (Xia et al., 2013). Xia et al. have reported that the lignan E2S inhibits cell viability and induces cell cycle arrest at the G1 phase in colon cancer HT29, HCT116, LoVo, and SW480 cells in a concentration-dependent manner (Xia et al., 2013).
However, their in vivo efficacy and mechanisms of action should be further investigated.

Sesquiterpenes, especially sesquiterpene lactones are a class of natural products with diverse structures and biological activities (Zhang et al., 2012; Wang et al., 2014). Wang et al. have recently 


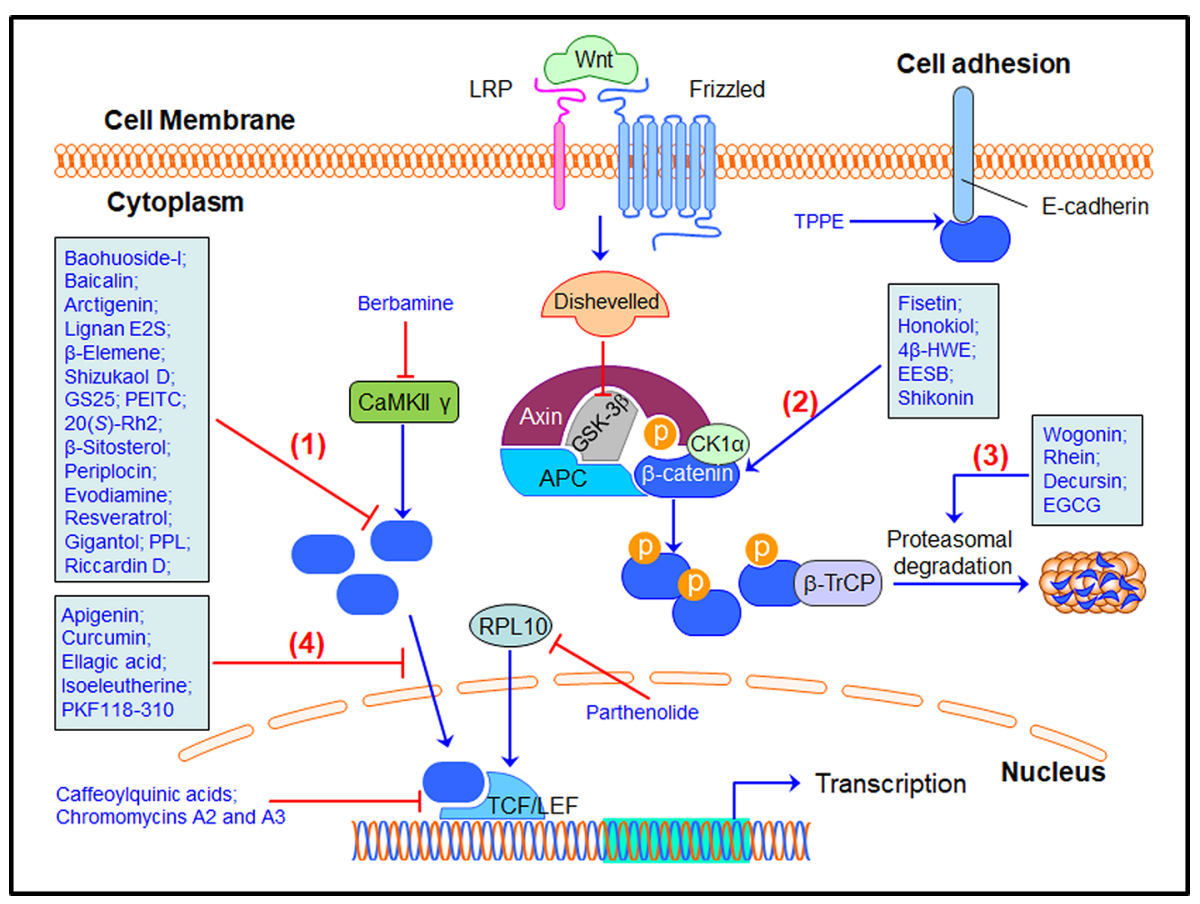

FIGURE 2 | Natural products targeting the $\beta$-catenin signaling pathway for cancer therapy. Many natural products have been discovered to inhibit the $\beta$-catenin signaling pathway through (1) down-regulating $\beta$-catenin expression, (2) modulating $\beta$-catenin phosphorylation, (3) promoting $\beta$-catenin protein degradation, (4)

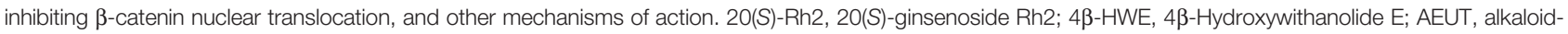
enriched extract of Uncaria tomentosa; APC, adenomatous polyposis coli; $\beta$-TrCP, $\beta$-Transducin repeat-containing protein; CK1 $\alpha$, casein kinase $1 \alpha$; EGCG, epigallocatechin-3-gallate; EESB, ethanol extract of Scutellaria barbata D. Don; GS25, 20(S)-25-OCH 3 -PPD; GSK3 $\beta$, glycogen synthase kinase 3ß; LRP, low-density lipoprotein receptor-related protein; PEITC, phenethyl isothiocyanate; PPL, polysaccharides from Phellinus linteus; TCF/LEF, T cell factor/lymphocyte enhancer factor; TPPE, Teucrium polium plant extract.

reported that the sesquiterpene $\beta$-elemene from Rhizoma zedoariae oil inhibits cell viability and induces cell cycle arrest at the G1 phase and apoptosis in cervical cancer SiHa cells (Wang L. $t$ al., 2018). $\beta$-Elemene has also been shown to suppress the migration and invasion of SiHa cells (Wang L. $t$ al., 2018). The mechanisms of action studies have found that $\beta$-elemene inhibits the $\beta$-catenin signaling by decreasing the expression levels of $\beta$-catenin and its coactivator TCF7 (Wang L. t al., 2018). The dimeric sesquiterpenes have shown more potent anticancer activities than their monomers by targeting oncogenic drivers (Qin et al., 2015a; Qin et al., 2015b). Tang et al. have recently identified shizukaol $\mathrm{D}$, a dimeric sesquiterpene as a $\beta$-catenin signaling inhibitor (Tang et al., 2016). It has been found that shizukaol D inhibits cell viability and colony formation and induces apoptosis in liver cancer cells by down-regulating the expression of $\beta$-catenin and its upstream regulators LRP, Dvl2, and Axin2 (Tang et al., 2016). The activation of $\beta$-catenin by wnt3a blocks shizukaol D-induced cell growth inhibition, indicating that the $\beta$-catenin signaling plays a critical role in the anticancer activity of this compound (Tang et al., 2016). However, the in vivo efficacy and safety of $\beta$-elemene and shizukaol $D$ have not been evaluated yet. It should also be examined whether these sesquiterpenes induce $\beta$-catenin degradation by disrupting the destruction complex.
Ginsenosides, the active components of the well-known herbal medicine Panax ginseng have shown a wide range of pharmacological activities, including anticancer activity (Nag et al., 2012). Recent studies have indicated that $\beta$-catenin signaling also plays an important role in the anticancer activities of ginsenosides (Bi et al., 2009; Chen et al., 2016). Bi et al. have found that ginsenoside $20(S)-25-\mathrm{OCH}_{3}-\mathrm{PPD}$ inhibits the viability and induces apoptosis in colon and lung cancer cells by downregulating the protein expression of $\beta$-catenin and its targets CDK4, cyclin D1, c-Myc, and TCF4 (Bi et al., 2009). More recently, Chen et al. have reported that 20(S)-ginsenoside Rh2 inhibits cell viability and induces cell cycle arrest at the G0/G1 phase and apoptosis in leukemia KG-1a cells by downregulating the expression of $\beta$-catenin at both protein and mRNA levels (Chen et al., 2016). Nevertheless, further studies should be performed to explore the precise mechanisms of action for the ginsenoside-mediated inhibition of $\beta$-catenin expression.

Sterols from medicinal plants have recently been shown to inhibit the $\beta$-catenin signaling (Baskar et al., 2010; Kim et al., 2017). Baskar et al. have found that $\beta$-sitosterol, a sterol compound from the traditional medicinal plant Asclepias curassavica Linn. inhibits cell growth and induces apoptosis in colon cancer COLO 320 DM cells (Baskar et al., 2010). $\beta$ Sitosterol has also shown chemopreventive effects on 1,2- 
dimethylhydrazine (DMH)-induced colon carcinogenesis in rats (Baskar et al., 2010). The in vitro and in vivo anti-colon cancer activity of $\beta$-sitosterol has been partially attributed to the downregulation of $\beta$-catenin expression by the compound (Baskar et al., 2010). Kim et al. have identified periplocin from the methanol extract of Telectadium dongnaiense bark as a new inhibitor of the $\beta$-catenin signaling (Kim et al., 2017). It has been reported that periplocin decreases the protein expression levels of $\beta$-catenin and its downstream targets, leading to the growth inhibition of colon cancer HCT116, SW480, HCT15, and LS174T cells (Kim et al., 2017). Nature-derived alkaloids have also exhibited potent anticancer activity by targeting the $\beta$-catenin signaling (Fu et al., 2011; Shi et al., 2016). Evodiamine, a quinolone alkaloid from Euodia rutaecarpa (Juss.) Benth. (Rutaceae) has been reported to inhibit the proliferation, invasion, and migration of hepatocellular carcinoma (HCC) HepG2 and SMMC-7721 cells in vitro and suppress tumor growth and angiogenesis in mice bearing H22 and SMMC-7721 xenograft tumors in vivo (Shi et al., 2016). The down-regulation of $\beta$-catenin protein expression by evodiamine has been found to contribute to its anti-HCC activity (Shi et al., 2016).

Several other natural products have been found to downregulate the expression of $\beta$-catenin, including resveratrol (Mitani et al., 2014; Mineda et al., 2019), phenethyl isothiocyanate (PEITC) (Chen et al., 2018), gigantol (Yu et al., 2018), polysaccharide from Phellinus linteus (Song et al., 2011), and riccardin D (Liu et al., 2012). Among them, resveratrol and PEITC are two welldocumented dietary anticancer chemopreventive compounds with multiple molecular targets (Mitani et al., 2014; Chen et al., 2018; Mineda et al., 2019). Recent studies have shown that resveratrol and PEITC also inhibit the $\beta$-catenin signaling; however, the importance of $\beta$-catenin in their anticancer activity is yet to be determined (Mitani et al., 2014; Chen et al., 2018; Mineda et al., 2019). Besides, gigantol from medicinal orchids and polysaccharides from Phellinus linteus have shown inhibitory effects on cancer cell growth and invasion by decreasing the protein levels of $\beta$-catenin and its targets (Song et al., 2011; Yu et al., 2018). Moreover, riccardin D from the liverwort plant Dumortiera hirsute has shown preventive effects on intestinal adenoma formation in $A P C^{\mathrm{Min} /+}$ mice (Liu et al., 2012). Although riccardin $\mathrm{D}$ has been shown to decrease the protein expression level of $\beta$-catenin in vivo, it is unknown how important $\beta$-catenin is in its anticancer activity (Liu et al., 2012).

\section{Modulate $\beta$-Catenin Phosphorylation}

Considering that $\beta$-catenin phosphorylation by GSK3 $\beta$ and $\mathrm{CK} 1 \alpha$ leads to its inactivation and degradation, directly promoting $\beta$-catenin phosphorylation has been proposed as an effective strategy to inhibit the $\beta$-catenin signaling pathway. Several natural products have recently been shown to inhibit cancer cell growth and metastasis by inducing $\beta$-catenin phosphorylation and inactivation (Table 1). Suh et al. have reported that fisetin, a flavonoid commonly found in various vegetables and fruits promotes the phosphorylation of $\beta$-catenin and decreases its nuclear level in colon cancer cells (Suh et al., 2009). It has also been found that fisetin down-regulates the expression of TCF1 and TCF4 in the nucleus and whole cancer cells (Suh et al., 2009). Consequently, fisetin inhibits cell viability and induces apoptosis in colon cancer HCT116 and HT29 cells (Suh et al., 2009). Honokiol, a lignan from the bark of Magnolia plants has been found to induce the phosphorylation of $\beta$ catenin at Ser45, Ser33/37, and Thr41 and reduce the $\beta$ catenin protein level in the nucleus (Singh and Katiyar, 2013b). Singh and Katiyar have also demonstrated that honokiol suppresses the migration of non-small cell lung cancer (NSCLC) cells (Singh and Katiyar, 2013b). However, the effects of fisetin and honokiol on the protein stability of $\beta$-catenin are yet to be determined. Moreover, the in vivo efficacy of both compounds should be examined in future studies.

Ye et al. have recently reported that $4 \beta$-hydroxywithanolide $\mathrm{E}$ (4 $\beta$-HWE), a natural withanolide from Physalis peruviana increases the level of phosphorylated $\beta$-catenin and decreases the levels of active nonphosphorylated form and total $\beta$-catenin in colon cancer HCT116 cells (Ye et al., 2019). 4 $\beta$-HWE has been shown to inhibit cell viability and induce cell cycle arrest at the G0/G1 phase and apoptosis in colon cancer cells with minimal cytotoxicity against normal colonic epithelial cells (CCD-841CoN) (Ye et al., 2019). More importantly, this compound has shown potent inhibitory effects on tumor growth in mice bearing HCT116 xenograft tumors, without causing significant changes in the average body weights of mice (Ye et al., 2019). Wei et al. have found that ethanol extract of Scutellaria barbata D. Don (EESB) inhibits the viability and proliferation of colon cancer HT-29 cells in vitro and suppresses the growth of HT-29 xenograft tumors in vivo (Wei et al., 2017). Mechanism of action studies have indicated that EESB induces $\beta$-catenin phosphorylation and reduces the expression level of total $\beta$ catenin in HT-29 cells (Wei et al., 2017). However, the active components in EESB that are responsible for EESB-induced $\beta$ catenin phosphorylation are yet to be determined.

Different from the aforementioned natural products that induce $\beta$-catenin phosphorylation, shikonin, an anthraquinone derivative from the root of lithospermum inhibits the phosphorylation of $\beta$-catenin in glioblastoma cells in a context-dependent manner. More specifically, this compound inhibits $\beta$-catenin phosphorylation at Tyr333 in U87 cells without altering its level in U251 cells (Zhang et al., 2015). However, shikonin has exhibited inhibitory effects on the proliferation, migration, and invasion of both U87 and U251 cell lines (Zhang et al., 2015). Further studies have indicated that shikonin also inhibits the PI3K/Akt pathway, which may also play a pivotal role in its anticancer activity (Zhang et al., 2015).

\section{Promote $\beta$-Catenin Protein Degradation}

Natural products that promote $\beta$-catenin protein degradation have been identified and shown anticancer efficacy in vitro and in vivo (Table 1) (Dashwood et al., 2005; Song et al., 2007; He et al., 2013; Liu et al., 2018). He et al. have characterized wogonin, a flavonoid from a Chinese medicinal herb Scutellaria radix (also called Huang-Qin) as an inducer of $\beta$-catenin protein degradation (He et al., 2013). It has been found that wogonin inhibits cell viability and colony formation and induces cell cycle arrest at the G1 phase in colon cancer cells in vitro. Wogonin has also been shown to suppress the growth of HCT116 xenograft 
tumors in vivo (He et al., 2013). Mechanistically, wogonin promotes $\beta$-catenin phosphorylation and degradation by activating the destruction complex proteins GSK3 $\beta$ and Axin. It has further been found that wogonin inhibits CDK8 activity, which is at least partially responsible for the inhibition of $\beta$ catenin signaling by the compound (He et al., 2013). Rhein, an anthraquinone derivative of rhubarb has also been shown to promote $\beta$-catenin phosphorylation at Ser33 and protein degradation, in which GSK3 $\beta$ plays a critical role (Liu et al., 2018). Liu et al. have further found that rhein inhibits cell proliferation and induces cell cycle arrest at the $S$ phase in HepG2 and Hela cells in vitro and suppresses the growth of HepG2 xenograft tumors in vivo (Liu et al., 2018).

Decursin, a pyranocoumarin identified from the roots of Angelica gigas Nakai has exhibited promising anti-prostate cancer efficacy (Song et al., 2007). Song et al. have recently screened and identified decursin as an inhibitor of the $\beta$-catenin signaling using HEK293 cells overexpressing $\beta$-catenin/TCF reporter gene (Song et al., 2007). Further studies have shown that decursin promotes the proteasomal degradation of $\beta$ catenin in a $\beta$-TrCP-dependent but GSK3 $\beta$-independent manner (Song et al., 2007). Epigallocatechin-3-gallate (EGCG), the most abundant polyphenol from green tea has also been characterized as an inducer of $\beta$-catenin protein degradation. Dashwood et al. have initially found that EGCG inhibits the $\beta$ catenin signaling by decreasing $\beta$-catenin protein levels in the nucleus, cytoplasm, and membrane-associated fraction (Dashwood et al., 2005). Moreover, EGCG has been shown to facilitate the trafficking of $\beta$-catenin into lysosomes, which contributes to the inhibition of $\beta$-catenin signaling (Dashwood et al., 2005). The inhibitory effects of EGCG on $\beta$-catenin signaling have further been confirmed in skin and colon cancer cells (Singh and Katiyar, 2013a; Oh et al., 2014; Chen et al., 2017). Oh et al. have reported that EGCG promotes $\beta$-catenin phosphorylation at Ser45 and Ser33/37 and proteasomal degradation in a $\beta$-TrCP-dependent manner (Oh et al., 2014). Chen et al. have shown that EGCG suppresses the properties of cancer stem cells (CSCs), inhibits proliferation, and induces apoptosis in colon cancer cells (Chen et al., 2017).

\section{Inhibit $\beta$-Catenin Nuclear Translocation}

$\beta$-Catenin acts as a coactivator for TCF/LEF-mediated transcription when the cytoplasmic $\beta$-catenin enters the nucleus and forms the $\beta$-catenin/TCF/LEF complex. Several natural products have been demonstrated to inhibit the nuclear translocation of $\beta$-catenin (Table 1), thereby inhibiting cancer cell growth and inducing apoptosis (Jaiswal et al., 2002; Shukla et al., 2007; Li et al., 2009; Leow et al., 2010; Anitha et al., 2013). Shukla et al. have reported that apigenin, a plant flavonoid has potent chemopreventive efficacy in TRAMP mice by preventing prostate tumorigenesis and metastasis and improving their overall survival (Shukla et al., 2007). Further studies have shown that apigenin decreases the nuclear level of $\beta$-catenin and increases the cytoplasmic level of E-cadherin in prostate cancer DU145 cells in vitro and in prostate tumors from TRAMP mice in vivo (Shukla et al., 2007). The well-known chemopreventive agent curcumin, a dietary polyphenol from the ginger family Curcuma longa has been shown to downregulate the nuclear level of $\beta$-catenin and disrupt the binding of $\beta$-catenin/TCF/LEF to the promoter DNA, thus blocking $\beta$ catenin-dependent gene expression, inhibiting cell viability, migration, and invasion, and inducing cell cycle arrest at the G2/M phase and apoptosis in osteosarcoma and colon cancer cells (Jaiswal et al., 2002; Leow et al., 2010). Jaiswal et al. have also found that curcumin promotes caspase-3-mediated degradation of $\beta$-catenin, E-cadherin, and APC, which may cause the loss of cell-cell adhesion (Jaiswal et al., 2002).

Ellagic acid, a nature-derived polyphenol has been found to suppress the development of oral carcinomas in the 7,12dimethylbenz[a]anthracene-induced hamster buccal pouch carcinogenesis model (Anitha et al., 2013). Its anticancer efficacy has been attributed to the inhibition of $\beta$-catenin nuclear translocation, while inactivation of NF- $\kappa B$ by ellagic acid may contribute to the inhibition of the $\beta$-catenin signaling (Anitha et al., 2013). In addition, isoeleutherine and toxoflavin (PKF118-310) have been shown to decrease the nuclear accumulation of $\beta$-catenin without affecting its cytoplasmic expression level (Li et al., 2009; Leow et al., 2010). PKF118-310 has also been found to inhibit the viability, migration, and invasion and induce cell cycle arrest at the G2/M phase and apoptosis in osteosarcoma U2OS cells (Leow et al., 2010).

\section{Others}

Several natural products have been reported to inhibit the $\beta$ catenin signaling by targeting the upstream regulators without direct effects on $\beta$-catenin itself (Table 1). Zhu et al. have recently identified a plant-derived sesquiterpene lactone, parthenolide as a small-molecule inhibitor of the $\beta$-catenin signaling through a high-throughput screening (Zhu et al., 2018). It has further been found that parthenolide directly binds to the ribosome protein RPL10, blocks the protein synthesis of TCF4/LEF1, and decreases their protein levels, therefore inhibiting $\beta$-catenin/TCF/LEF-mediated gene transcription and the proliferation of colon cancer cells, without affecting the stability and subcellular distribution of $\beta$ catenin (Zhu et al., 2018). Gu et al. have found that berbamine, an alkaloid from traditional Chinese medicine Berberis amurensis specifically binds to the ATP-binding pocket of CaMKII $\gamma$ and inhibits its kinase activity, thereby inhibiting its downstream targets, including $\beta$-catenin (Gu et al., 2012). It has been further found that berbamine induces apoptotic and autophagic death of leukemia cells in vitro and suppresses tumor growth in mice bearing tyrosine kinase inhibitors (TKI)-resistant K562 or primary chronic myeloid leukemia (CML) xenograft tumors in vivo (Gu et al., 2012).

Natural products that restore the E-cadherin/ $\beta$-catenin complex have been found to prevent cancer metastasis (Table 1) (Kandouz et al., 2010). Kandouz et al. have found that Teucrium polium plant extract (TPPE) enhances the formation of E-cadherin/ $\beta$-catenin complex, inhibits $\beta$-catenin phosphorylation, and reduces invasion and motility of prostate cancer PC3 and DU145 cells (Kandouz et al., 2010). TPPE has also been shown to inhibit prostate cancer cell proliferation and induce cell cycle arrest at the S phase (Kandouz et al., 2010). In 
addition, several other natural products (Table 1), including alkaloid-enriched extract of Uncaria tomentosa, dinactin, caffeoylquinic acids, and chromomycins A2 and A3 have shown inhibitory effects on the $\beta$-catenin signaling in cancer cells; however, their detailed mechanisms of action are not clear yet (Gurrola-Diaz et al., 2011; Taira et al., 2014; Toume et al., 2014; Hussain et al., 2019).

\section{CONCLUSIONS AND FUTURE PERSPECTIVES}

Thanks to the substantial advances in understanding the molecular basis of cancer initiation, progression, metastasis, and drug resistance, several promising molecular targets have been characterized for cancer drug discovery, including $\beta$ catenin (Cui et al., 2018; Qi et al., 2020). Considering the critical role of $\beta$-catenin signaling in cancer development and progression, several targeting strategies have been developed to inhibit $\beta$-catenin, resulting in the identification of various types of $\beta$-catenin inhibitors (Krishnamurthy and Kurzrock, 2018; Qin et al., 2018b). Natural products and natural product-derived compounds remain an important source for the discovery and development of new anticancer drugs (Qian et al., 2013; Qin et al., 2018a; Davison and Brimble, 2019). Several natural products have been shown to inhibit the $\beta$-catenin signaling via different molecular mechanisms, including, but not limited to, 1) down-regulating $\beta$-catenin expression, 2) modulating $\beta$-catenin phosphorylation and inducing its inactivation, 3 ) promoting $\beta$ catenin protein ubiquitination and proteasomal degradation, 4) inhibiting $\beta$-catenin nuclear translocation, and 5) other.

The majority of natural product $\beta$-catenin inhibitors have been shown to down-regulate $\beta$-catenin expression at protein and/or mRNA levels and suppress cancer cell growth in vitro and in vivo. However, the detailed molecular mechanisms for the down-regulation of $\beta$-catenin expression by these natural products are not clear yet, which largely hinders the further development of these natural products as anticancer agents. Of note, simply reducing the expression of an oncogene may not only induce cancer cell death but also cause other adverse effects (Wang et al., 2019). It has been found that $\beta$-catenin interacts with E-cadherin to stabilize cell-cell adhesion and prevent metastasis (Huber and Weis, 2001). Therefore, downregulating the expression of membrane-bound $\beta$-catenin may promote metastasis, while targeting active $\beta$-catenin without

\section{REFERENCES}

Aberle, H., Bauer, A., Stappert, J., Kispert, A., and Kemler, R. (1997). beta-catenin is a target for the ubiquitin-proteasome pathway. EMBO J. 16, 3797-3804. doi: 10.1093/emboj/16.13.3797

Amit, S., Hatzubai, A., Birman, Y., Andersen, J. S., Ben-Shushan, E., Mann, M., et al. (2002). Axin-mediated CKI phosphorylation of beta-catenin at Ser 45: a molecular switch for the Wnt pathway. Genes Dev. 16, 1066-1076. doi: 10.1101/gad.230302

Anitha, P., Priyadarsini, R. V., Kavitha, K., Thiyagarajan, P., and Nagini, S. (2013). Ellagic acid coordinately attenuates Wnt/beta-catenin and NF-kappaB affecting the $\beta$-catenin/E-cadherin complex is critical for developing safe and effective anticancer agent.

Inhibiting active $\beta$-catenin through modulating $\beta$-catenin phosphorylation and promoting its proteasomal degradation in the cytoplasm and/or inhibiting the translocation of $\beta$-catenin from cytoplasm to nucleus is more promising than reducing the level of $\beta$-catenin in whole cells. Although several natural products have been identified to inhibit the $\beta$-catenin signaling through these mechanisms of action, it is still unclear whether $\beta$ catenin is the real molecular target of these natural products. Therefore, the precise mechanisms of action, especially binding mechanisms should be further investigated. If the binding of these natural products to $\beta$-catenin is confirmed, it may be considered to develop $\beta$-catenin PROTACs (proteolysis targeting chimeras) by using these compounds for cancer prevention and therapy (Neklesa et al., 2017). Moreover, further evaluation of these compounds in more clinically relevant cancer models should be performed in the future.

\section{AUTHOR CONTRIBUTIONS}

J-JQ conceptualized the manuscript. W-KY, Z-YX, LY, SM, BX, and $\mathrm{X}-\mathrm{DC}$ collected the literature, wrote the manuscript and made the figures. J-JQ edited and made significant revisions to the manuscript. All authors contributed to the article and approved the submitted version.

\section{FUNDING}

This study was supported by National Natural Science Foundation of China (81903842), Program of Zhejiang Provincial TCM Sci-tech Plan (2020ZZ005), and Zhejiang Chinese Medical University Startup Funding (111100E014).

\section{ACKNOWLEDGMENTS}

We thank the current and former members of our laboratories and collaborators for their contributions to the publications cited in this review article. The research fields in natural products and $\beta$-catenin are rapidly growing, and we apologize for not being able to cite all the recent publications, due to space limitation.

signaling pathways to induce intrinsic apoptosis in an animal model of oral oncogenesis. Eur. J. Nutr. 52, 75-84. doi: 10.1007/s00394-011-0288-y

Baskar, A. A., Ignacimuthu, S., Paulraj, G. M., and Al Numair, K. S. (2010). Chemopreventive potential of beta-Sitosterol in experimental colon cancer model-an in vitro and In vivo study. BMC Complement Altern. Med. 10, 24. doi: 10.1186/1472-6882-10-24

Bi, X., Zhao, Y., Fang, W., and Yang, W. (2009). Anticancer activity of Panax notoginseng extract 20(S)-25-OCH3-PPD: Targetting beta-catenin signalling. Clin. Exp. Pharmacol. Physiol. 36, 1074-1078. doi: 10.1111/j.1440-1681.2009.05203.x

Chen, Y., Liu, Z. H., Xia, J., Li, X. P., Li, K. Q., Xiong, W., et al. (2016). 20(S)ginsenoside Rh2 inhibits the proliferation and induces the apoptosis of KG-1a 
cells through the Wnt/beta-catenin signaling pathway. Oncol. Rep. 36, 137146. doi: $10.3892 / o r .2016 .4774$

Chen, Y., Wang, X. Q., Zhang, Q., Zhu, J. Y., Li, Y., Xie, C. F., et al. (2017). (-)-Epigallocatechin-3-Gallate Inhibits Colorectal Cancer Stem Cells by Suppressing Wnt/beta-Catenin Pathway. Nutrients 9, 572. doi: 10.3390/ nu9060572

Chen, Y., Li, Y., Wang, X. Q., Meng, Y., Zhang, Q., Zhu, J. Y., et al. (2018). Phenethyl isothiocyanate inhibits colorectal cancer stem cells by suppressing Wnt/beta-catenin pathway. Phytother. Res. 32, 2447-2455. doi: 10.1002/ ptr.6183

Cheng, X., Qin, J., Zeng, Q., Zhang, S., Zhang, F., Yan, S., et al. (2011a). Taraxasterane-type triterpene and neolignans from Geum japonicum Thunb. var. chinense F. Bolle. Planta Med. 77, 2061-2065. doi: 10.1055/s-00311280091

Cheng, X. R., Jin, H. Z., Qin, J. J., Fu, J. J., and Zhang, W. D. (2011b). Chemical constituents of plants from the genus Geum. Chem. Biodivers 8, 203-222. doi: 10.1002/cbdv.200900347

Cheng, X., Xu, X., Chen, D., Zhao, F., and Wang, W. (2019). Therapeutic potential of targeting the Wnt/beta-catenin signaling pathway in colorectal cancer. BioMed. Pharmacother. 110, 473-481. doi: 10.1016/j.biopha.2018.11.082

Cui, C., Zhou, X., Zhang, W., Qu, Y., and Ke, X. (2018). Is beta-Catenin a Druggable Target for Cancer Therapy? Trends Biochem. Sci. 43, 623-634. doi: 10.1016/j.tibs.2018.06.003

Dashwood, W. M., Carter, O., Al-Fageeh, M., Li, Q., and Dashwood, R. H. (2005). Lysosomal trafficking of beta-catenin induced by the tea polyphenol epigallocatechin-3-gallate. Mutat. Res. 591, 161-172. doi: 10.1016/ j.mrfmmm.2005.03.029

Davison, E. K., and Brimble, M. A. (2019). Natural product derived privileged scaffolds in drug discovery. Curr. Opin. Chem. Biol. 52, 1-8. doi: 10.1016/ j.cbpa.2018.12.007

Dong, J., Qin, Z., Zhang, W. D., Cheng, G., Yehuda, A. G., Ashby, C. R.Jr., et al. (2020). Medicinal chemistry strategies to discover P-glycoprotein inhibitors: An update. Drug Resist. Update 49, 100681. doi: 10.1016/j.drup.2020.100681

Feng, T., Cao, W., Shen, W., Zhang, L., Gu, X., Guo, Y., et al. (2017). Arctigenin inhibits STAT3 and exhibits anticancer potential in human triple-negative breast cancer therapy. Oncotarget 8, 329-344. doi: 10.18632/oncotarget.13393

Fu, J. J., Qin, J. J., Zeng, Q., Huang, Y., Zhang, W. D., and Jin, H. Z. (2011). Two new monoterpene alkaloid derivatives from the roots of Incarvillea arguta. Arch. Pharm. Res. 34, 199-202. doi: 10.1007/s12272-011-0203-3

Gu, Y., Chen, T., Meng, Z., Gan, Y., Xu, X., Lou, G., et al. (2012). CaMKII gamma, a critical regulator of CML stem/progenitor cells, is a target of the natural product berbamine. Blood 120, 4829-4839. doi: 10.1182/blood-2012-06434894

Gurrola-Diaz, C. M., Garcia-Lopez, P. M., Gulewicz, K., Pilarski, R., and Dihlmann, S. (2011). Inhibitory mechanisms of two Uncaria tomentosa extracts affecting the Wnt-signaling pathway. Phytomedicine 18, 683-690. doi: 10.1016/j.phymed.2010.11.002

He, L., Lu, N., Dai, Q., Zhao, Y., Zhao, L., Wang, H., et al. (2013). Wogonin induced G1 cell cycle arrest by regulating Wnt/beta-catenin signaling pathway and inactivating CDK8 in human colorectal cancer carcinoma cells. Toxicology 312, 36-47. doi: 10.1016/j.tox.2013.07.013

Huber, A. H., and Weis, W. I. (2001). The structure of the beta-catenin/E-cadherin complex and the molecular basis of diverse ligand recognition by beta-catenin. Cell 105, 391-402. doi: 10.1016/S0092-8674(01)00330-0

Hussain, A., Dar, M. S., Bano, N., Hossain, M. M., Basit, R., Bhat, A. Q., et al. (2019). Identification of dinactin, a macrolide antibiotic, as a natural productbased small molecule targeting Wnt/beta-catenin signaling pathway in cancer cells. Cancer Chemother. Pharmacol. 84, 551-559. doi: 10.1007/s00280-01903870-x

Jaiswal, A. S., Marlow, B. P., Gupta, N., and Narayan, S. (2002). Beta-cateninmediated transactivation and cell-cell adhesion pathways are important in curcumin (diferuylmethane)-induced growth arrest and apoptosis in colon cancer cells. Oncogene 21, 8414-8427. doi: 10.1038/sj.onc.1205947

Kandouz, M., Alachkar, A., Zhang, L., Dekhil, H., Chehna, F., Yasmeen, A., et al. (2010). Teucrium polium plant extract inhibits cell invasion and motility of human prostate cancer cells via the restoration of the E-cadherin/catenin complex. J. Ethnopharmacol. 129, 410-415. doi: 10.1016/j.jep.2009.10.035
Kim, W. K., Bach, D. H., Ryu, H. W., Oh, J., Park, H. J., Hong, J. Y., et al. (2017). Cytotoxic activities of Telectadium dongnaiense and its constituents by inhibition of the Wnt/beta-catenin signaling pathway. Phytomedicine 34, 136-142. doi: 10.1016/j.phymed.2017.08.008

Krishnamurthy, N., and Kurzrock, R. (2018). Targeting the Wnt/beta-catenin pathway in cancer: Update on effectors and inhibitors. Cancer Treat Rev. 62, 50-60. doi: 10.1016/j.ctrv.2017.11.002

Lee, J., Imm, J. Y., and Lee, S. H. (2017). beta-Catenin Mediates Anti-adipogenic and Anticancer Effects of Arctigenin in Preadipocytes and Breast Cancer Cells. J. Agric. Food Chem. 65, 2513-2520. doi: 10.1021/acs.jafc.7b00112

Leow, P. C., Tian, Q., Ong, Z. Y., Yang, Z., and Ee, P. L. (2010). Antitumor activity of natural compounds, curcumin and PKF118-310, as Wnt/beta-catenin antagonists against human osteosarcoma cells. Invest. New Drugs 28, 766782. doi: 10.1007/s10637-009-9311-z

Li, X., Ohtsuki, T., Koyano, T., Kowithayakorn, T., and Ishibashi, M. (2009). New Wnt/beta-catenin signaling inhibitors isolated from Eleutherine palmifolia. Chem. Asian J. 4, 540-547. doi: 10.1002/asia.200800354

Li, X., Yang, X., Liu, Y., Gong, N., Yao, W., Chen, P., et al. (2013). Japonicone A suppresses growth of Burkitt lymphoma cells through its effect on NF-kappaB. Clin. Cancer Res. 19, 2917-2928. doi: 10.1158/1078-0432.CCR-12-3258

Liu, C., Li, Y., Semenov, M., Han, C., Baeg, G. H., Tan, Y., et al. (2002). Control of beta-catenin phosphorylation/degradation by a dual-kinase mechanism. Cell 108, 837-847. doi: 10.1016/S0092-8674(02)00685-2

Liu, H. P., Gao, Z. H., Cui, S. X., Sun, D. F., Wang, Y., Zhao, C. R., et al. (2012). Inhibition of intestinal adenoma formation in $\mathrm{APC}(\mathrm{Min} /+)$ mice by Riccardin D, a natural product derived from liverwort plant Dumortiera hirsuta. PloS One 7, e33243. doi: 10.1371/journal.pone.0033243

Liu, S., Wang, J., Shao, T., Song, P., Kong, Q., Hua, H., et al. (2018). The natural agent rhein induces beta-catenin degradation and tumour growth arrest. J. Cell Mol. Med. 22, 589-599. doi: 10.1111/jcmm.13346

Mineda, A., Nishimura, M., Kagawa, T., Takiguchi, E., Kawakita, T., Abe, A., et al. (2019). Resveratrol suppresses proliferation and induces apoptosis of uterine sarcoma cells by inhibiting the Wnt signaling pathway. Exp. Ther. Med. 17, 2242-2246. doi: 10.3892/etm.2019.7209

Mitani, T., Harada, N., Tanimori, S., Nakano, Y., Inui, H., and Yamaji, R. (2014). Resveratrol inhibits hypoxia-inducible factor-1alpha-mediated androgen receptor signaling and represses tumor progression in castration-resistant prostate cancer. J. Nutr. Sci. Vitaminol. (Tokyo) 60, 276-282. doi: 10.3177/ jnsv.60.276

Nag, S. A., Qin, J. J., Wang, W., Wang, M. H., Wang, H., and Zhang, R. (2012). Ginsenosides as Anticancer Agents: In vitro and in vivo Activities, StructureActivity Relationships, and Molecular Mechanisms of Action. Front. Pharmacol. 3, 25. doi: 10.3389/fphar.2012.00025

Neklesa, T. K., Winkler, J. D., and Crews, C. M. (2017). Targeted protein degradation by PROTACs. Pharmacol. Ther. 174, 138-144. doi: 10.1016/ j.pharmthera.2017.02.027

Newman, D. J., and Cragg, G. M. (2020). Natural Products as Sources of New Drugs over the Nearly Four Decades from 01/1981 to 09/2019. J. Nat. Prod. 83, 770-803. doi: 10.1021/acs.jnatprod.9b01285

Oh, S., Gwak, J., Park, S., and Yang, C. S. (2014). Green tea polyphenol EGCG suppresses Wnt/beta-catenin signaling by promoting GSK-3beta- and PP2Aindependent beta-catenin phosphorylation/degradation. Biofactors 40, 586595. doi: 10.1002/biof.1185

Orford, K., Crockett, C., Jensen, J. P., Weissman, A. M., and Byers, S. W. (1997). Serine phosphorylation-regulated ubiquitination and degradation of betacatenin. J. Biol. Chem. 272, 24735-24738. doi: 10.1074/jbc.272.40.24735

Ozawa, M., Baribault, H., and Kemler, R. (1989). The cytoplasmic domain of the cell adhesion molecule uvomorulin associates with three independent proteins structurally related in different species. EMBO J. 8, 1711-1717. doi: 10.1002/ j.1460-2075.1989.tb03563.x

Ozawa, M., Ringwald, M., and Kemler, R. (1990). Uvomorulin-catenin complex formation is regulated by a specific domain in the cytoplasmic region of the cell adhesion molecule. Proc. Natl. Acad. Sci. U. S. A 87, 4246-4250. doi: 10.1073/ pnas.87.11.4246

Pai, S. G., Carneiro, B. A., Mota, J. M., Costa, R., Leite, C. A., Barroso-Sousa, R., et al. (2017). Wnt/beta-catenin pathway: modulating anticancer immune response. J. Hematol. Oncol. 10, 101. doi: 10.1186/s13045-017-0471-6 
Qi, S. M., Cheng, G., Cheng, X. D., Xu, Z., Xu, B., Zhang, W. D., et al. (2020). Targeting USP7-Mediated Deubiquitination of MDM2/MDMX-p53 Pathway for Cancer Therapy: Are We There Yet? Front. Cell Dev. Biol. 8, 233. doi: $10.3389 /$ fcell.2020.00233

Qian, B., Nag, S. A., Su, Y., Voruganti, S., Qin, J. J., Zhang, R., et al. (2013). miRNAs in cancer prevention and treatment and as molecular targets for natural product anticancer agents. Curr. Cancer Drug Targets 13, 519-541. doi: $10.2174 / 15680096113139990031$

Qin, J. J., Wang, W., Voruganti, S., Wang, H., Zhang, W. D., and Zhang, R. (2015a). Identification of a new class of natural product MDM2 inhibitor: In vitro and in vivo anti-breast cancer activities and target validation. Oncotarget 6, 2623-2640. doi: 10.18632/oncotarget.3098

Qin, J. J., Wang, W., Voruganti, S., Wang, H., Zhang, W. D., and Zhang, R. (2015b). Inhibiting NFAT1 for breast cancer therapy: New insights into the mechanism of action of MDM2 inhibitor JapA. Oncotarget 6, 33106-33119. doi: 10.18632 /oncotarget.5851

Qin, J., Wang, W., and Zhang, R. (2017). Novel natural product therapeutics targeting both inflammation and cancer. Chin. J. Nat. Med. 15, 401-416. doi: 10.1016/S1875-5364(17)30062-6

Qin, J. J., Li, X., Hunt, C., Wang, W., Wang, H., and Zhang, R. (2018a). Natural products targeting the p53-MDM2 pathway and mutant p53: Recent advances and implications in cancer medicine. Genes Dis. 5, 204-219. doi: 10.1016/ j.gendis.2018.07.002

Qin, J. J., Wang, W., Li, X., Deokar, H., Buolamwini, J. K., and Zhang, R. (2018b). Inhibiting beta-Catenin by beta-Carboline-Type MDM2 Inhibitor for Pancreatic Cancer Therapy. Front. Pharmacol. 9, 5. doi: 10.3389/fphar. 2018.00005

Riggleman, B., Schedl, P., and Wieschaus, E. (1990). Spatial expression of the Drosophila segment polarity gene armadillo is posttranscriptionally regulated by wingless. Cell 63, 549-560. doi: 10.1016/0092-8674(90)90451-J

Shi, L., Yang, F., Luo, F., Liu, Y., Zhang, F., Zou, M., et al. (2016). Evodiamine exerts anti-tumor effects against hepatocellular carcinoma through inhibiting beta-catenin-mediated angiogenesis. Tumour. Biol. 37, 12791-12803. doi: 10.1007/s13277-016-5251-3

Shukla, S., Maclennan, G. T., Flask, C. A., Fu, P., Mishra, A., Resnick, M. I., et al. (2007). Blockade of beta-catenin signaling by plant flavonoid apigenin suppresses prostate carcinogenesis in TRAMP mice. Cancer Res. 67, 69256935. doi: 10.1158/0008-5472.CAN-07-0717

Singh, T., and Katiyar, S. K. (2013a). Green tea polyphenol, (-)-epigallocatechin-3gallate, induces toxicity in human skin cancer cells by targeting beta-catenin signaling. Toxicol. Appl. Pharmacol. 273, 418-424. doi: 10.1016/ j.taap.2013.09.021

Singh, T., and Katiyar, S. K. (2013b). Honokiol inhibits non-small cell lung cancer cell migration by targeting PGE(2)-mediated activation of beta-catenin signaling. PloS One 8, e60749. doi: 10.1371/journal.pone.0060749

Song, G. Y., Lee, J. H., Cho, M., Park, B. S., Kim, D. E., and Oh, S. (2007). Decursin suppresses human androgen-independent PC3 prostate cancer cell proliferation by promoting the degradation of beta-catenin. Mol. Pharmacol. 72, 1599-1606. doi: 10.1124/mol.107.040253

Song, K. S., Li, G., Kim, J. S., Jing, K., Kim, T. D., Kim, J. P., et al. (2011). Proteinbound polysaccharide from Phellinus linteus inhibits tumor growth, invasion, and angiogenesis and alters Wnt/beta-catenin in SW480 human colon cancer cells. BMC Cancer 11, 307. doi: 10.1186/1471-2407-11-307

Stamos, J. L., and Weis, W. I. (2013). The beta-catenin destruction complex. Cold Spring Harb. Perspect. Biol. 5, a007898. doi: 10.1101/cshperspect.a007898

Suh, Y., Afaq, F., Johnson, J. J., and Mukhtar, H. (2009). A plant flavonoid fisetin induces apoptosis in colon cancer cells by inhibition of COX2 and Wnt/EGFR/ NF-kappaB-signaling pathways. Carcinogenesis 30, 300-307. doi: 10.1093/ carcin/bgn269

Taira, J., Uehara, M., Tsuchida, E., and Ohmine, W. (2014). Inhibition of the betacatenin/Tcf signaling by caffeoylquinic acids in sweet potato leaf through down regulation of the Tcf-4 transcription. J. Agric. Food Chem. 62, 167-172. doi: $10.1021 / \mathrm{jf} 404411 \mathrm{r}$

Tang, L., Zhu, H., Yang, X., Xie, F., Peng, J., Jiang, D., et al. (2016). Shizukaol D, a Dimeric Sesquiterpene Isolated from Chloranthus serratus, Represses the Growth of Human Liver Cancer Cells by Modulating Wnt Signalling Pathway. PloS One 11, e0152012. doi: 10.1371/journal.pone.0152012
Toume, K., Tsukahara, K., Ito, H., Arai, M. A., and Ishibashi, M. (2014). Chromomycins A2 and A3 from marine actinomycetes with TRAIL resistance-overcoming and Wnt signal inhibitory activities. Mar. Drugs 12, 3466-3476. doi: 10.3390/md12063466

Wang, L., Lu, A., Liu, X., Sang, M., Shan, B., Meng, F., et al. (2011). The flavonoid Baohuoside-I inhibits cell growth and downregulates survivin and cyclin D1 expression in esophageal carcinoma via beta-catenin-dependent signaling. Oncol. Rep. 26, 1149-1156. doi: 10.3892/or.2011.1400

Wang, G. W., Qin, J. J., Cheng, X. R., Shen, Y. H., Shan, L., Jin, H. Z., et al. (2014). Inula sesquiterpenoids: structural diversity, cytotoxicity and anti-tumor activity. Expert Opin. Invest. Drugs 23, 317-345. doi: 10.1517/13543784.2014.868882

Wang, L., Zhao, Y., Wu, Q., Guan, Y., and Wu, X. (2018a). Therapeutic effects of beta-elemene via attenuation of the Wnt/beta-catenin signaling pathway in cervical cancer cells. Mol. Med. Rep. 17, 4299-4306. doi: 10.3892/mmr.2018.8455

Wang, W., Qin, J. J., Li, X., Tao, G., Wang, Q., Wu, X., et al. (2018b). Prevention of prostate cancer by natural product MDM2 inhibitor GS25: in vitro and in vivo activities and molecular mechanisms. Carcinogenesis 39, 1026-1036. doi: 10.1093/carcin/bgy063

Wang, W., Qin, J. J., Rajaei, M., Li, X., Yu, X., Hunt, C., et al. (2020). Targeting MDM2 for novel molecular therapy: Beyond oncology. Med. Res. Rev. 40, 856880. doi: 10.1002/med.21637

Wang, W., Yang, J., Liao, Y. Y., Cheng, G., Chen, J., Mo, S., et al. (2020). Aspeterreurone A, a Cytotoxic Dihydrobenzofuran-Phenyl Acrylate Hybrid from the Deep-Sea-Derived Fungus Aspergillus terreus CC-S06-18. J. Nat. Prod. doi: 10.1021/acs.jnatprod.0c00189

Wei, L. H., Lin, J. M., Chu, J. F., Chen, H. W., Li, Q. Y., and Peng, J. (2017). Scutellaria barbata D. Don inhibits colorectal cancer growth via suppression of Wnt/beta-catenin signaling pathway. Chin. J. Integr. Med. 23, 858-863. doi: 10.1007/s11655-017-2775-3

Wieschaus, E., Nusslein-Volhard, C., and Jurgens, G. (1984). Mutations affecting the pattern of the larval cuticle inDrosophila melanogaster : III. Zygotic loci on the X-chromosome and fourth chromosome. Wilehm Roux Arch. Dev. Biol. 193, 296-307. doi: 10.1007/BF00848158

$\mathrm{Wu}, \mathrm{G}$., and $\mathrm{He}, \mathrm{X}$. (2006). Threonine 41 in beta-catenin serves as a key phosphorylation relay residue in beta-catenin degradation. Biochemistry 45 , 5319-5323. doi: 10.1021/bi0601149

Xia, X., Bi, X., Wu, W., Mou, Y., Hou, Y., Zhang, K., et al. (2013). Inhibition of betacatenin signaling involved in the biological activities of a lignan E2S isolated from Carya cathayensis fruits. Planta Med. 79, 1648-1652. doi: 10.1055/s-0033-1351020

Ye, Z. N., Yuan, F., Liu, J. Q., Peng, X. R., An, T., Li, X., et al. (2019). Physalis peruviana-Derived 4beta-Hydroxywithanolide E, a Novel Antagonist of Wnt Signaling, Inhibits Colorectal Cancer In Vitro and In Vivo. Molecules 24, 1146. doi: $10.3390 /$ molecules 24061146

Yu, S., Wang, Z., Su, Z., Song, J., Zhou, L., Sun, Q., et al. (2018). Gigantol inhibits Wnt/beta-catenin signaling and exhibits anticancer activity in breast cancer cells. BMC Complement Altern. Med. 18, 59. doi: 10.1186/s12906-018-2108-x

Yuan, L., Xu, Z. Y., Ruan, S. M., Mo, S., Qin, J. J., and Cheng, X. D. (2020). Long non-coding RNAs towards precision medicine in gastric cancer: early diagnosis, treatment, and drug resistance. Mol. Cancer 19, 96. doi: 10.1186/ s12943-020-01219-0

Zhang, S. D., Qin, J. J., Jin, H. Z., Yin, Y. H., Li, H. L., Yang, X. W., et al. (2012). Sesquiterpenoids from Inula racemosa Hook. f. inhibit nitric oxide production. Planta Med. 78, 166-171. doi: 10.1055/s-0031-1280294

Zhang, F. Y., Hu, Y., Que, Z. Y., Wang, P., Liu, Y. H., Wang, Z. H., et al. (2015). Shikonin Inhibits the Migration and Invasion of Human Glioblastoma Cells by Targeting Phosphorylated beta-Catenin and Phosphorylated PI3K/Akt: A Potential Mechanism for the Anti-Glioma Efficacy of a Traditional Chinese Herbal Medicine. Int. J. Mol. Sci. 16, 23823-23848. doi: 10.3390/ijms161023823

Zhang, J., Wang, W., Zhou, Y., Yang, J., Xu, J., Xu, Z., et al. (2020). Terphenyllin Suppresses Orthotopic Pancreatic Tumor Growth and Prevents Metastasis in Mice. Front. Pharmacol. 11, 457. doi: 10.3389/fphar.2020.00457

Zhang, X., Wang, L., and Qu, Y. (2020). Targeting the beta-catenin signaling for cancer therapy. Pharmacol. Res. 104794. doi: 10.1016/j.phrs.2020.104794

Zhou, T., Zhang, A., Kuang, G., Gong, X., Jiang, R., Lin, D., et al. (2017). Baicalin inhibits the metastasis of highly aggressive breast cancer cells by reversing epithelial-to-mesenchymal transition by targeting beta-catenin signaling. Oncol. Rep. 38, 3599-3607. doi: 10.3892/or.2017.6011 
Zhu, J. X., Qin, J. J., Chang, R. J., Zeng, Q., Cheng, X. R., Zhang, F., et al. (2012a). Chemical constituents of plants from the genus Euonymus. Chem. Biodivers 9, 1055-1076. doi: 10.1002/cbdv.201100170

Zhu, J. X., Ren, J., Qin, J. J., Cheng, X. R., Zeng, Q., Zhang, F., et al. (2012b). Phenylpropanoids and lignanoids from Euonymus acanthocarpus. Arch. Pharm. Res. 35, 1739-1747. doi: 10.1007/s12272-012-1005-y

Zhu, X., Yuan, C., Tian, C., Li, C., Nie, F., Song, X., et al. (2018). The plant sesquiterpene lactone parthenolide inhibits Wnt/beta-catenin signaling by blocking synthesis of the transcriptional regulators TCF4/LEF1. J. Biol. Chem. 293, 5335-5344. doi: 10.1074/jbc.M117.819300
Conflict of Interest: The authors declare that the research was conducted in the absence of any commercial or financial relationships that could be construed as a potential conflict of interest.

Copyright $\odot 2020 \mathrm{Yu}, \mathrm{Xu}, \mathrm{Yuan}, \mathrm{Mo}, \mathrm{Xu}$, Cheng and Qin. This is an open-access article distributed under the terms of the Creative Commons Attribution License (CC BY). The use, distribution or reproduction in other forums is permitted, provided the original author(s) and the copyright owner(s) are credited and that the original publication in this journal is cited, in accordance with accepted academic practice. No use, distribution or reproduction is permitted which does not comply with these terms. 